University of Wollongong

Research Online

Faculty of Engineering and Information

Faculty of Engineering and Information

Sciences - Papers: Part B

Sciences

2018

Computational Thinking and Coding Subject in Primary Schools:

Methodological Approach Based on Alternative Cooperative and Individual

Learning Cycles

Elena Vlahu-Gjorgievska

University of Wollongong, elenavg@uow.edu.au

Maja Videnovik

Center for Innovation and Digital Education

Vladimir Trajkovik

Saints Cyril and Methodius University of Skopje

Follow this and additional works at: https://ro.uow.edu.au/eispapers1

Part of the Engineering Commons, and the Science and Technology Studies Commons

Research Online is the open access institutional repository for the University of Wollongong. For further information contact the UOW Library: research-pubs@uow.edu.au 


\title{
Computational Thinking and Coding Subject in Primary Schools: Methodological Approach Based on Alternative Cooperative and Individual Learning Cycles
}

\author{
Abstract \\ Many countries have included or consider to include computational thinking in their educational curricula. \\ This creates the need for a carefully planned educational approach involving different stakeholders as \\ policymakers, educators and students. These stakeholders are the main carriers of the educational \\ reforms thus their perspectives create various challenges and risks. In this paper, we propose a \\ pedagogical approach of teaching coding through games and gamification of the learning process. The \\ flipped classroom is used in order to address the shortcomings in teacher training and deliver learning \\ outcomes in student-centred, fun and engaging way. Proposed solution includes a spiral curriculum \\ implemented in 4 cycles that alternate cooperative and individual learning approach. The approach was \\ evaluated with more than 199 students from 6 different schools. Evaluation analyses were focused on the \\ achieved learning experience identifying differences between male and female students, as well as \\ students with different level of access to ICT resources. The results confirm the benefits of the proposed \\ solution. \\ Disciplines \\ Engineering | Science and Technology Studies

\section{Publication Details} \\ Vlahu-Gjorgievska, E., Videnovik, M. \& Trajkovik, V. (2018). Computational Thinking and Coding Subject in \\ Primary Schools: Methodological Approach Based on Alternative Cooperative and Individual Learning \\ Cycles. 2018 IEEE International Conference on Teaching, Assessment, and Learning for Engineering \\ (TALE) (pp. 77-83). United States: IEEE.
}




\section{Computational Thinking and Coding Subject in Primary Schools: Methodological Approach Based on Alternative Cooperative and Individual Learning Cycles}

\author{
Elena Vlahu-Gjorgievska \\ School of Computing and Information \\ Technology \\ University of Wollongong \\ Wollongong, Australia \\ elenavg@uow.edu.au
}

\author{
Maja Videnovik \\ Center for innovation and digital \\ education \\ NGO Dig-Ed \\ Skopje, Macedonia \\ majavidenovik@gmail.com
}

\author{
Vladimir Trajkovik \\ Faculty of Computer Science and \\ Engineering \\ Ss. Cyril and Methodius University \\ Skopje, Macedonia \\ trvlado@finki.ukim.mk
}

\begin{abstract}
Many countries have included or consider to include computational thinking in their educational curricula. This creates the need for a carefully planned educational approach involving different stakeholders as policymakers, educators and students. These stakeholders are the main carriers of the educational reforms thus their perspectives create various challenges and risks. In this paper, we propose a pedagogical approach of teaching coding through games and gamification of the learning process. The flipped classroom is used in order to address the shortcomings in teacher training and deliver learning outcomes in student-centred, fun and engaging way. Proposed solution includes a spiral curriculum implemented in $\mathbf{4}$ cycles that alternate cooperative and individual learning approach. The approach was evaluated with more than 199 students from 6 different schools. Evaluation analyses were focused on the achieved learning experience identifying differences between male and female students, as well as students with different level of access to ICT resources. The results confirm the benefits of the proposed solution.
\end{abstract}

Keywords-coding, programming, computational thinking, gamification, primary schools

\section{INTRODUCTION}

In this era of technological invasion, when the information and communication technologies (ICT) are applied in every aspect of our lives, developing computational thinking in children is a very popular topic. The expansion of ICT is changing the labour market where the new jobs require more than basic information technology knowledge and programming capability. Furthermore, the analysis of the digital labour market showed that ICT-related jobs are being created much more quickly than employment in other sectors, demanding ICT specialists more than ever [1]. This skills gap can be overcome with an immediate modernization of the ICT education by acquiring solid ICT knowledge in the basic education. Thus, the development of the basic coding skills and the digital literacy in primary education is inevitable.

Required educational reforms on a global scale must consider different stakeholders. The policymakers are the one that needs to consider the conditions and initiate the reforms.
On the other side are the educators that need to implement proposed reforms and students as consumers of the reforms [2]. These stakeholders have different needs and perspectives. The policymakers are interested in obtained results and how they reflect on the national level (e.g Pisa testing, Euridice results) [3]. The educators need to define the right strategy for implementation of the reforms. This requires time to understand specifics on national, regional and schools level, as well as proper training. This is very important since the educators, in general, are not digital natives, so they lack of training in different digital tools, and constantly face the need to improve their digital literacy. Finally, students need to understand the importance of digital competencies and apply them in their education. This is not always an easy task having in mind different workload put on the students, their current and general interests and needs.

Setting a logical framework for teaching and learning computational thinking and coding in primary education must be based on carefully selected tools, practices and approaches in teaching, learning and instruction. The most important to be considered is that the subject should be present in order to address students' possible change of focus from general to specific knowledge. This is particularly sensitive in the period of students' life when they discover their initial interest for a future profession, thus the effect can be inverse [4].

In order to develop students' computational thinking ability, there are many extra curricula coding activities and programming courses offered for schoolchildren. In addition, many countries have included programming subjects as compulsory or elective in the primary or secondary education curricula.

ICT and programming is part of the educational curricula in New Zealand, Estonia, Cyprus, UK, Australia, Poland, South Korea and USA, either as a compulsory or elective subject [5][6]. In Greece, Spain, Netherlands and Japan, programming is part of the primary or secondary education as well [7]-[10]. Some Danish primary schools are involved in pilot studies where 1st to 9th-grade students work with Scratch and Lego 
MindStorms in STEM (Science, Technology, Engineering, and Mathematics) subjects [11]

However, coding subjects need to have a strong pedagogical focus on student-centred approaches, where the students and their motivation are the driving forces of the learning process. Thus, we are proposing a methodology that incorporates teamwork and individual learning using different technological tools and educational paradigms.

The paper presents an approach for learning how to code in primary schools that include cooperative and competitive cycles that span over several school years and uses different learning paradigms (as game-based learning, gamification, flipped classroom and project-based learning). The design provides basic skills and knowledge for the large student population and enables a higher level of programming knowledge for the more interested students. The spiral curriculum allows some of the topics to be revised in the higher classes and required knowledge to be upgraded. Thus, the levels of difficulty and profound knowledge of the students increase throughout the school years. In the terms of coding, this means that the students start their learning by creating simple programs and add a level of code complexity in each following year. The proposed approach is general and can be applied in primary schools in different countries and students from 9 to 14 years old.

The next section is the background. In the third section we give an overview of the methodology in the proposed approach, and in the fourth section we are presenting a case study of the primary schools in the Republic of Macedonia. The fifth section summarizes the results of the case study. The discussion of the results is covered in the sixth section and the last section is the conclusion.

\section{BACKGROUND}

Computational Thinking (CT) means solving problems, designing systems and understanding human behaviour based on computer science concepts [12]. Even though CT is essential in the development of computer applications, it can be used in solving different problems (from computer and noncomputer nature) in an intelligent and imaginative way [13]. The main goal of $\mathrm{CT}$ is to upgrade creative, critical thinking and other competencies with the skill of using computers and algorithms. CT supports learning and development by decomposition (breaking down problems into parts), pattern recognition (observing patterns, trends and regularities), abstraction (identifying the general principles) and algorithm design (developing the step-by-step instructions for problemsolving). Some of the initiatives for developing computational thinking include educational robotics, visual programming tools and video game programming [14].

Today, students are truly representatives of digital natives. Most of them are very familiar with internet technology, mobile phones, and feel very comfortable when using the web or mobile apps, especially games. It comes naturally to use this technology, which is an essential part of students life, as a tool for achieving learning outcomes related to computational thinking and learning to code.
The important point in creating technology-enhanced classroom is establishing a partnership between students and teacher, where everyone is an active participant in the learning process. Teachers must find ways to make the learning process attractive and entertaining for the students. As students are constantly surrounded by technology, its integration in the classroom through different approaches is more than necessary.

Children play games with a lot of focus, energy and enthusiasm. Children also learn during play [15]. This commitment should be transmitted to the learning in the school. By using games, or gamification, new and powerful ways of learning in the classrooms can be created [16]. Game-based learning (GBL) and gamification of learning process more adequately address the manner in which students learn today and engage them in meaningful learning more successfully than traditional learning methods.

Gamification is the use of game design elements in nongame contexts and has been applied in different areas including education and training. There are several gamification design frameworks addressing different elements and components of the gamification design process [17]. For example, Octalyis framework defines gamification as a design that places the most emphasis on human motivation in the process, introducing eight core drives: meaning, accomplishment, empowerment, ownership, social influence, scarcity, unpredictability and avoidance [18]. Gamification, formed by game elements such as reward and competition, provides visible incentives for students' behaviour, thus can increase cognitive load and achievement levels [19]. It can support learning providing collaboration and self-guided study, and increase motivation, engagement, creativity and retention of the students [20]. Beside the positive factors that drive teachers' intentions of using gamification, Sánchez-Mena \& MartíParreño [21] identified several barriers as well. Most common barriers that can prevent teachers from using gamification are lack of resources, students' lack of interest in gamification and suitability of gamification for a particular subject.

Game-based learning can be successfully developed and implemented in the learning environment by combining game design and instructional design approaches, as well as by considering various issues such as learning theories, the theory of play, mobile platform and technologies (for mobile games), game design, and instructional design [22].

Even though gamification is often used as a synonym for Game-Based Learning, these two concepts are sufficiently distinct. In this context, GBL refers to the adoption of game artefacts as educational tools for learning (a specific subject), and gamification is an educational strategy based on the application of game mechanisms in the learning process [23].

In the attempts to address the challenge of making games for education enjoyable, yet effective, researchers and educational practitioners are increasingly turning their attention towards so-called serious games for education [24]. Welldesigned serious games teach by stimulating the imagination, sparking curiosity, fostering discussion and encouraging a spirit of competitive exploration across a variety of domains. Games offer students opportunities to reach goals that are not focused just on learning facts but enable development of skills such as 
problem-solving, decision making and strategic planning at the same time [25]. Computer games do not only integrate knowing and doing, but they also "bring together ways of knowing, ways of doing, ways of being, and ways of caring: the situated understandings, effective social practices, powerful identities, and shared values that make someone an expert" [26].

A child's play can be important for developing social skills as well. The social interaction with other children supports children in understanding social "rules". Lev Vygotsky [27] introduces "the zone of proximal development" where he explains how it is possible to expand what students learn in a social context with a peer that have different knowledge backgrounds. This requires increased student activity, which is also promoted in today's classroom.

One approach that can be used in encouraging the students to be active and make use of their own experiences is the Flipped Classroom. Flipped Classroom can be defined as a class that utilizes practices and problem solving led primarily by the students [28]. As an instructional strategy, flipped classroom reverses the traditional learning environment by allowing students to be prepared for the lecture before coming to class (using online videos and materials) and using class time for student-centred learning [29]. Thus, this approach inspires student-centred learning, reduce the achievement gap among students and personalize the learning in the classroom [30].

On the other side, in order to get a better understanding of how students can learn from experiences, David A. Kolb introduced the experiential learning cycle [31]. An experience requires reflection that explains what happened during learning. Then, in the next phase, learning can start from this experience utilizing new lessons from the previous experience. Reflection is thus considered to be an important bridge between knowledge and learning. Reflection processes can be facilitated in different ways. Donald Schön argues that one can reflect during and after experience and that reflection can be on different levels [32].

Johnson and Johnson define three types of goal structures available to teachers during the instruction phase of the learning process: cooperative, competitive, and individualistic [33]. Computer-assisted cooperative instruction promotes greater quantity and quality of daily achievement, more successful problem solving, and higher performance on factual recognition, application, and problem-solving test items than does computer-assisted competitive or individualistic learning [34].

Cooperative efforts produce higher quality problem-solving skills than competitive efforts on a wide variety of problems [35]. Possible reasons why cooperation may increase problemsolving success include the exchange of information and insights among cooperators, the generation of a variety of strategies to solve the problem, increased ability to translate the problem statement into equations, and the development of a shared cognitive representation of the problem [36].

The individual cycles supported by technology enables the student to master the learning topic [37]. Additionally, should be noted that a team's overall performance and quality of cooperation amplifies the positive effects of individual learning as well [38]. Thus, it is important to combine individual and cooperative learning cycles.

\section{Proposed Methodological ApProACH}

Educational innovations in elementary schools should have a strong pedagogical focus on student-centred approaches facilitated by ICT, whereby teachers should play more of a coaching role. However, the future amendments of the curriculum for the ICT subjects, as well as of the ICT topics horizontally represented into various subjects, should follow principles [39].

The proposed methodology incorporates teamwork and individual learning using different technological tools and educational paradigms as a constructivist approach, projectbased learning, game-based learning, flipped classroom, cooperative learning and available massive open online classes (MOOCs).

The methodology consists of three mandatory and one optional cycle (Fig. 1). In every cycle, the students practice the same principles of coding (as defined by the "Learning to Code" subject program) but using different tools. In this way, students' knowledge increases in an incremental way, enabling students to progress according to their interest in the subject. The proposed tools are selected based on the cost-effectiveness criteria, and they can be exchanged with other tools as well.

The first, introduction, cycle uses cooperative game-based learning and flipped classroom for introducing basic concepts of coding and problem-solving. By using cooperative gamebased approach, the students are focused on the elements of code, rather than on certain coding platform or environment. In the same time, the students learn from each other and compete with different teams. This approach tends to involve all students (including those from vulnerable categories with less learning, social or economic abilities) in the learning process. The Flipped Classroom paradigm is very suitable for this cycle since the primary role of the teacher is to share with students the solutions of the problems noted by students. The second cycle is individual block-based code learning, which allows students to master coding principles on an individual level. In this cycle, students are individually mastering block-based coding and start to get familiar with the basic elements of some programming environment. There are plenty of MOOCs that can be used for this purpose. The third cycle is based on collaborative project-based learning using the programming environment. The students are focused on different projects they can develop for other subjects. In this cycle, the focus is on understanding the programming tools and its application in different context. This opens a possibility for most advanced students to start learning programming languages within the coding clubs, and for teachers to investigate possibilities for introducing a specific programming language as a tool within the "Learning to Code" subject in the last year of primary school (9th grade).

There are many specific games, programming platforms and tools that can be utilized in this approach. List of some possible options is presented in Table 1. 


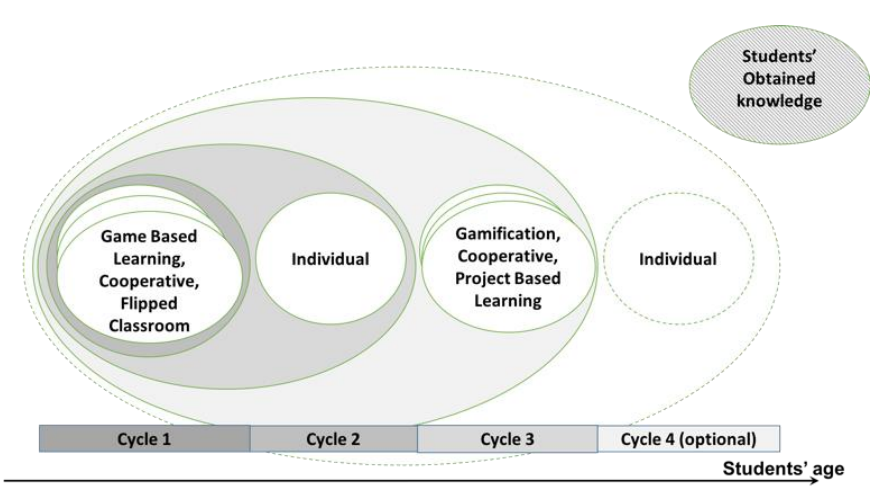

Fig. 1. Methodology cycles

For example, Scottie Go! board game can be used in the first cycle. Scottie Go! uses the mobile app with a camerabased interface that is very popular among students. The board game is a puzzle-based game where students are asked to create instructions for alien "Scottie" to solve some problem. The flipped classroom paradigm is very suitable for this example, due to the familiarity of the students with the mobile and board games.

In the second cycle, the "Scratch" e-learning platform can be used. It allows students to master coding principles on an individual level. The basic principles of Scratch coding platform are already familiar to the students due to the fact that they are the same as the elements of the board game from the previous cycle. Thus, in this cycle students are mastering block-based coding on an individual level, and start to get familiar with the basic elements of the programming environment. There are also plenty of on-line materials that can be used for this purpose.

The third cycle is based on collaborative project-based learning using "Micro:bit" programming environment. Micro:bit Environment uses both hardware and software elements that are programmed in Scratch compatible environment. So, the students are focused on developing different projects that can be used in other subjects. In addition, they are starting to get familiar with programming sensors, actuators, and basic of embedded programming principles. The Micro:bit platform can be programmed using different programming languages including Python.

\section{CASE Study - InTRoduction OF PROGRAmMing SubJECTS} IN THE PRIMARY SCHOOLS IN THE REPUBLIC OF MACEDONIA

The students from primary schools in R. Macedonia according to various international testing lack problem-solving skills as well as the habit of team-based collaboration. On the other hand, they are digital natives and do not have a problem using different technology tools. Due to the very slow process of amendment of the curriculum at national level and outdated teaching and instruction methods for coding and generally in all areas of digital education, a serious lack of attitude, persistence, self-confidence, and ability to face the challenge is identified in university settings when the students encounter a situation of solving problems in more complex projects.
TABLE I. TOOLS AND PARADIGMS That CAN BE USED IN THE PROPOSED APPROACH

\begin{tabular}{|l|l|l|l|l|}
\hline \multicolumn{1}{|c|}{ Cycle } & \multicolumn{3}{|c|}{ Tools } & \multicolumn{1}{|c|}{$\begin{array}{c}\text { Educational } \\
\text { Paradigm }\end{array}$} \\
\hline First & $\begin{array}{l}\text { Scottie } \\
\text { Go! }\end{array}$ & $\begin{array}{l}\text { Code } \\
\text { Combat }\end{array}$ & Puzzles & $\begin{array}{l}\text { Cooperative } \\
\text { game-based } \\
\text { flipped classroom }\end{array}$ \\
\hline Second & Scratch & $\begin{array}{l}\text { Code } \\
\text { Monkey }\end{array}$ & Minecraft & $\begin{array}{l}\text { Individual } \\
\text { MOOC }\end{array}$ \\
\hline Third & Micro:bit & Lego & Microduino & $\begin{array}{l}\text { Collaborative } \\
\text { project-based } \\
\text { gamification }\end{array}$ \\
\hline Optional & Payton & Java & Ruby & $\begin{array}{l}\text { Individual } \\
\text { MOOC }\end{array}$ \\
\hline
\end{tabular}

Having this in mind, the policymakers in R. Macedonia implemented "Working with computers and programming" subject. This subject is perceived as a possibility to reduce digital competency gap among teachers and students, increase the problem-solving skills of students (aiming to improve the results on international testing), as well as to address the needs for labour market demanding skills' set.

The subject "Working with computers and programming" is taught starting from the 3rd grade (8 years old students). The implementation of the subject started four years ago. According to the curriculum, students should learn about algorithms and concepts of algorithm and programming, develop skills of algorithmic thinking through game-based learning, understand the concept of programming, create programs in different programming languages, as well as understand coding errors and solve it.

The subject raised enormous interest among the students. At the same time, the subject created serious obstacles that prevent its successful integration in the teaching process. Some of the issues are related to the teachers' lack of knowledge in the area, as well as the deficiency of quality resources for teaching. Comparing to the teachers in most of the European countries, digital competences of Macedonian teachers are at a low level. The general understanding of using technology in classes is limited to presentation tools and simple web queries. Macedonian teachers have only a few days of training provided by the state. This training is insufficient in terms of developing acquired digital competences and creating actual lesson plans for their classes. This is especially emphasized in lower grades.

Our approach requires implementation of the subject "Working with computers and programming" using several digital tools: ScootieGo [40], Scratch [41], Micro:bit [42] and Python [43].

In order to examine the students' attitudes toward using different tools for learning to code and achieving learning outcomes, we conducted a survey with students from third up to ninth grade. In the survey participated classes from 6 different schools, balancing the total male-female distribution of students and urban-rural distribution of schools. The students have used suggested digital tools in their regular classes and after we obtained the results for their overall experience.

The focus of the research was on the advantages of using selected digital tools in the educational process, and not on the students' achievements. We wanted to explore students' 
interest in the tools, its ease of use, correspondence to educational goals and the ability that tools provide in reaching the desired outcome. Therefore, we tested only cooperative parts of the education process through the quality of students' achieved experience.

We surveyed students' perception for two specific tools: Scottie Go! board game and BBC Micro:bit platform. The first one is implemented by a cooperative game based flipped classroom, while the second one is implemented using cooperative project-based learning with gamification elements.

The first part of the survey was used for gathering demographic information about the participants (students' age, gender and school year) and their experience of playing games. The second part was designed to measure students' attitudes toward learning to code with different tools, using a five-point Likert scale, with answer choices ranging from "strongly disagree" (1) to "strongly agree" (5). This part of the survey was meant to obtain information about students' quality of experience $(\mathrm{QoE})$ in using presented tools. Tested measures were: is the tool easy to use, its educational value, correspondence to educational goals, and students' subjective attitude for using the corresponding tool in the educational process.

\section{RESULTS}

Students (with different age and sex) from six different primary schools in Macedonia have used Scottie Go! and Micro:bit as tools for learning to code. The survey was conducted in urban areas (well-equipped) schools and in rural area (not well-equipped) schools as well.

A total number of students that participate in the survey is 121 with $52 \%$ male and $48 \%$ female students. The survey about Micro:bit was distributed among 78 students $(50.6 \%$ male and $49.4 \%$ female). Results from the survey show that $71 \%$ of students play games every day or very often, and $68 \%$ of them are playing games on mobile phone or tablet. This was certainly a thought-provoking fact, which supports the idea for game-based learning and gamification in the classroom.

Results from the survey regarding students' attitudes toward learning to code using Scottie Go! and Micro:bit are presented in Table 2. In Table 3 are presented students' QoE grouped by their place of living (urban and rural area). The mean value is calculated by adding up all the values from the student answers and then dividing that sum by the number of students.

\section{DISCUSSION}

The results (Table 2) show that the students are very interested in using Scottie Go! and Micro:bit platform as educational tools for learning to code. In their opinion, both tools are easy to use, preferring Scottie Go! (4.85) more than Micro:bit. Instructions for the tools are easy to follow and students like the interactivity of the tools. Results for learning how to use Scottie Go! for coding were 4.89 and for Micro:bit the results are slightly lower 4.42 .
TABLE II. RESUlTS FOR STUDENTS' ATTITUDE TOWARDS USING SCOTTIE GO! AND MICRO:BIT FOR LEARNING TO CODE BASED ON THEIR GENDER

\begin{tabular}{|c|c|c|c|c|c|c|}
\hline \multirow{3}{*}{ Question } & \multicolumn{3}{|c|}{$\begin{array}{c}\text { Scottie Go! } \\
\text { N=121 }\end{array}$} & \multicolumn{3}{|c|}{$\begin{array}{c}\text { Micro:bit } \\
\mathrm{N}=77\end{array}$} \\
\hline & Total & Male & Female & Total & Male & Female \\
\hline & Mean & Mean & Mean & Mean & Mean & Mean \\
\hline $\begin{array}{l}\text { Interface of } \\
\text { the tool is } \\
\text { easy to use }\end{array}$ & 4.86 & 4.81 & 4.90 & 4.43 & 4.39 & 4.46 \\
\hline $\begin{array}{l}\text { The tool has } \\
\text { clear } \\
\text { instructions }\end{array}$ & 4.69 & 4.51 & 4.86 & 4.50 & 4.49 & 4.50 \\
\hline $\begin{array}{l}\text { Searching for } \\
\text { the right } \\
\text { solution } \\
\text { encouraged } \\
\text { me to think } \\
\text { and I had a } \\
\text { desire to learn }\end{array}$ & 4.77 & 4.68 & 4.86 & 4.45 & 4.51 & 4.39 \\
\hline $\begin{array}{l}\text { I can easy } \\
\text { achieve tools's } \\
\text { requirements }\end{array}$ & 4.49 & 4.33 & 4.64 & 4.37 & 4.50 & 4.24 \\
\hline $\begin{array}{l}\text { It was easy to } \\
\text { learn how to } \\
\text { use Scottie } \\
\text { Go!/ } \\
\text { Micro:bit }\end{array}$ & 4.90 & 4.86 & 4.93 & 4.47 & 4.56 & 4.37 \\
\hline $\begin{array}{l}\text { I have fun } \\
\text { while playing } \\
\text { Scottie Go!/ } \\
\text { Micro:bit }\end{array}$ & 4.74 & 4.57 & 4.90 & 4.61 & 4.66 & 4.55 \\
\hline $\begin{array}{l}\text { It is a } \\
\text { collaborative } \\
\text { game }\end{array}$ & 4.91 & 4.84 & 4.97 & 4.49 & 4.55 & 4.42 \\
\hline $\begin{array}{l}\text { It is } \\
\text { interesting to } \\
\text { learn with } \\
\text { Scottie Go!/ } \\
\text { Micro:bit }\end{array}$ & 4.89 & 4.86 & 4.91 & 4.64 & 4.64 & 4.63 \\
\hline $\begin{array}{l}\text { I prefer to } \\
\text { learn using } \\
\text { games rather } \\
\text { than } \\
\text { traditional } \\
\text { way a } \\
\text { learning }\end{array}$ & 4.65 & 4.67 & 4.62 & 4.48 & 4.53 & 4.42 \\
\hline $\begin{array}{lr}\text { Using } & \text { this } \\
\text { way } & \text { of } \\
\text { learning } \\
\text { through } \\
\text { game, a } \\
\text { achieve the } \\
\text { desired results } \\
\text { faster and } \\
\text { more } \\
\text { successfully } \\
\end{array}$ & 4.64 & 4.51 & 4.76 & 4.49 & 4.56 & 4.42 \\
\hline $\begin{array}{l}\text { Using the } \\
\text { game makes } \\
\text { the subjects } \\
\text { more } \\
\text { interesting }\end{array}$ & 4.81 & 4.87 & 4.74 & 4.53 & 4.56 & 4.50 \\
\hline $\begin{array}{l}\text { I like the } \\
\text { overall } \\
\text { experience }\end{array}$ & 4.76 & 4.75 & 4.76 & 4.57 & 4.61 & 4.53 \\
\hline $\begin{array}{l}\text { Interface of } \\
\text { the tool is } \\
\text { easy to use }\end{array}$ & 4.86 & 4.81 & 4.90 & 4.43 & 4.39 & 4.46 \\
\hline
\end{tabular}


TABLE III. RESUlTS FOR STUDENTS' ATTITUDE TOWARDS USING SCOTTIE GO! AND MICRO:BIT IN URBAN AND RURAL SCHOOLS

\begin{tabular}{|l|l|l|l|l|}
\hline \multicolumn{1}{|c|}{ Question } & \multicolumn{2}{|c|}{ Scottie Go! } & \multicolumn{2}{c|}{ Micro:bit } \\
\cline { 2 - 5 } & Urban & Rural & Urban & Rural \\
\cline { 2 - 5 } & Mean & Mean & Mean & Mean \\
\hline $\begin{array}{l}\text { Interface of the tool is easy to } \\
\text { use }\end{array}$ & 4.93 & 4.62 & 4.57 & 4.15 \\
\hline The tool has clear instructions & 4.85 & 4.34 & 4.69 & 4.12 \\
\hline $\begin{array}{l}\text { Searching for the right } \\
\text { solution encouraged me to } \\
\text { think and I had a desire to } \\
\text { learn }\end{array}$ & 4.86 & 4.52 & 4.49 & 4.15 \\
\hline $\begin{array}{l}\text { I can easy achieve tools's } \\
\text { requirements }\end{array}$ & 4.65 & 3.97 & 4.37 & 4.04 \\
\hline $\begin{array}{l}\text { It was easy to learn how to use } \\
\text { Scottie Go! / Micro:bit }\end{array}$ & 4.95 & 4.76 & 4.58 & 4.12 \\
\hline $\begin{array}{l}\text { I have fun while playing } \\
\text { Scottie Go! / Micro:bit }\end{array}$ & 4.92 & 4.82 & 4.63 & 4.31 \\
\hline It is a collaborative game & 4.91 & 4.90 & 4.59 & 4.19 \\
\hline $\begin{array}{l}\text { It is interesting to learn with } \\
\text { Scottie Go! / Micro:bit }\end{array}$ & 4.91 & 4.83 & 4.59 & 4.54 \\
\hline $\begin{array}{l}\text { I prefer to learn using games } \\
\text { rather than a traditional way } \\
\text { of learning }\end{array}$ & 4.85 & 4.68 & 4.58 & 3.92 \\
\hline $\begin{array}{l}\text { Using this way of learning } \\
\text { through a game, I achieve the } \\
\text { desired results faster and more } \\
\text { successfully }\end{array}$ & 4.73 & 4.52 & 4.55 & 4.19 \\
\hline $\begin{array}{l}\text { Using the game makes the } \\
\text { subjects more interesting }\end{array}$ & 4.90 & 4.90 & 4.59 & 4.28 \\
\hline $\begin{array}{l}\text { I like the overall experience } \\
\text { Interface of the tool is easy to } \\
\text { use }\end{array}$ & 4.87 & 4.76 & 4.75 & 4.15 \\
\hline
\end{tabular}

This result is expected since Micro:bit is planned to be used in the third cycle of the proposed approach when students have already developed a level of computational thinking.

Students have positive attitudes regarding use of Scottie Go! and Micro:bit in the educational context as well (Table 2). The students are challenged to use the tools for finding the right solution, which raises their interest and motivation for learning. Another benefit of it is the students' active participation in the classroom and persistence in achieving educational goals. According to the survey's results, most of the students easy achieve tools' requirements (Scottie Go! - 4.48 and Micro:bit 4.26), which strength the possibilities of introducing flipped classroom.

The overall quality of students' experience is very high (Table 2), and they find learning with those tools very interesting (4.88 for Scottie Go! and 4.57 for Micro:bit). A good starting point is that the students have fun while using those tools, which can lead to successful integration of the tools in the classroom and achieving educational goals. Students prefer this kind of learning more than a traditional classroom. In their opinion, using this approach they can achieve desired results much faster and more successfully. Students would like to continue to use those tools for learning, especially Scottie Go! (4.75).

All these results (Table 2 and Table 3) show that integration of the proposed tools (Scottie Go! and Micro:bit) for learning to code will lead to successful achievement of learning outcomes and increase students' satisfaction from the learning process. All students were introduced to coding for the first time, so we cannot analyse the results regarding students' attitudes towards presented tools based on students' age. However, having in mind that the students with no previous knowledge of coding have slightly more positive attitudes for Scottie Go! than Micro:bit (overall experience for Scottie Go! is 4.75 and for Micro:bit is 4.55), can be a confirmation that Scottie Go! is more suitable for the first, introduction cycle in our approach.

Regarding the gender, results presented in Table 2 show that female students have more positive attitudes concerning Scottie Go! than male students. But the situation with Micro:bit is opposite. Male students have more positive attitudes towards Micro:bit than female. That was expected due to the fact that female students are more cooperative (Scottie Go! characteristic) and male students are more competitive. This finding is aligned with the previous literature findings [34].

Students from the urban area have a slightly more positive experience using both learning tools (Table 3 ). We believe that it reflects the availability of resources in urban and rural areas.

\section{CONCLUSION}

In this paper, we propose an approach that addresses the needs of students by developing a pedagogical approach of teaching to code through games and gamification of the learning process. The approach proposes a spiral curriculum implemented in 4 cycles that alternate cooperative and individual learning approach.

The proposed methodological approach combines different tools and educational techniques in order to achieve maximum educational effects. It differs from documented practices by taking care of both educational needs of the students and schools capacities to address those needs. Additionally, the flipped classroom is used in order to address the shortcomings in teacher training and to deliver learning outcomes in student centred, fun and engaging way.

The proposed approached is initially evaluated with a pilot study conducted in the primary schools in the Republic of Macedonia. Our primary goal was to determine the acceptance of the tools integrated into the methodology. The initial results show that the students are very keen to adopt the technology (offered tools Scottie Go! and Micro:bit) and want to be active participants in the educational process of learning to code. Further analyses towards students' expectations from different gender and unequal technological opportunities (rural vs urban schools) and gaps can be valuable sources as well. Additional research is required to explore the teachers' satisfaction, as well as the acceptance of the proposed methodology as a general approach in a primary school programming subjects' curriculum.

The results presented in this paper show that the presented approach and tools offered are highly acceptable in primary schools in the Republic of Macedonia. However, our approach is general enough and presented results are a good base for pilot studies exploring its adoption in primary schools in other countries across the world. 


\section{REFERENCES}

[1] European Comission. (2014). Digital agenda for Europe [Online]. Available: http://eige.europa.eu/resources/digital_agenda_en.pdf

[2] M. Fullan, "The three stories of education reform," Phi Delta Kappan, vol. 81 , no. 8 , p. $581,2000$.

[3] S. Sellar, G. Thompson, and D. Rutkowski, The global education race: Taking the measure of PISA and international testing. Brush Education, 2017.

[4] H.C. Kelman, "Processes of opinion change," in Attitude Change, $1^{\text {st }}$ ed. New York: Routledge, 1968, ch. 8, pp. 205-233.

[5] C. Duncan, and T. Bell, "A pilot computer science and programming course for primary school students," in Workshop in Primary and Secondary Computing Educ., London, UK, 2015, pp. 39-48.

[6] F. Heintz, L. Mannila, and T. Färnqvist, "A review of models for introducing computational thinking, computer science and computing in K-12 education," in IEEE Frontiers Educ. Conf., Erie, PA, 2016, pp. 19.

[7] E. Fokides, "Students learning to program by developing games: Results of a year-long project in primary school settings," JITE: Research, vol 16, pp. 475-505, 2017.

[8] N. van Es, and J. Jeuring, "Designing and comparing two scratch-based teaching approaches for students aged 10-12 years," in 17th Koli Calling Int. Conf. Computing Educ. Research, Koli, FI, 2017, pp. 178-182.

[9] D. Pérez-Marín, R. Hijón-Neira, and M. Martín-Lope, “A methodology proposal based on metaphors to teach programming to children," IEEE Revista Iberoamericana de Tecnologias del Aprendizaje (IEEE RITA), vol.13, no.1, 2018, pp. 46-53.

[10] H. Tsukamoto, Y. Takemura, H. Nagumo, I. Ikeda, A. Monden, and K.I Matsumoto, "Programming education for primary school children using a textual programming language," in IEEE Frontiers Educ. Conf., El Paso, TX, 2015, pp. 1-7.

[11] B.B. Allsopp, "Playful programming products vs. programming concepts matrix," in 11th European Conf. Games Based Learning, Graz, AT, 2017 , p. 1 .

[12] J. Wing, "Computational thinking," Commun. ACM, vol. 49, no. 3, pp. 33-36, 2006.

[13] E.K. Urrutia, J.M. Ocaña, D. Pérez-Marín, and S. Tamayo, "A first proposal of pedagogic conversational agents to develop computational thinking in children," in 5th Int. Conf. Technological Ecosystems for Enhancing Multiculturality, Cadis, ES, 2017, p. 2.

[14] A.M. Pinto-Llorente, S.C. Martín, M.C. González, and F.J. GarcíaPeñalvo, "Developing computational thinking via the visual programming tool: Lego education WeDo," in 4th Int. Conf. Technological Ecosystems for Enhancing Multiculturality, Salamanca, ES, 2016, pp. 45-50.

[15] J. Huizinga, Homo ludens: a study of the play element in culture. Routledge, 1949.

[16] I. Glover, "Play as you learn: Gamification as a technique for motivating learners," in EdMedia: World Conf. Educational Media and Technology, Victoria, CA, 2013, pp. 1999-2008.

[17] A. Mora, D. Riera, C. Gonzalez, and J. Arnedo-Moreno, "A literature review of gamification design frameworks," in 7th Int. Conf. Games and Virtual Worlds for Serious Applicat. (VS-Games), Skovde, SE, 2015, pp. $1-8$

[18] Y. Chou. (2013). Octalysis - the complete gamification framework [Online]. Available: https://yukaichou.com/gamificationexamples/octalysis-complete-gamification-framework/

[19] Z. Turan, Z. Avinc, K. Kara, and Y. Goktas, "Gamification and education: Achievements, cognitive loads, and views of students," iJET, vol. 11, no. 7, pp. 64-69, 2016.

[20] C. Dichev, and D. Dicheva, "Gamifying education: what is known, what is believed and what remains uncertain: A critical review," Int. J. Educational Technology in Higher Educ., vol. 14, no. 1, p. 9, 2017.
[21] A. Sánchez-Mena and J. Martí-Parreño, "Drivers and barriers to adopting gamification: Teachers' perspectives," EJEL, vol. 15 , no. 5, pp. 434-443, 2017

[22] S.B. Zaibon, and N. Shiratuddin, "Mobile game-based learning (mGBL) engineering model as a systematic development approach," in Proc. Global Conf. Learning and Technology, Penang, MY, 2010, pp. 1862 1871.

[23] I. Caponetto, J. Earp, and M. Ott, "Gamification and education: A literature review," in 8th European Conf. Games Based Learning, Berlin, DE, 2014, vol. 1, p. 50 .

[24] T. Hainey, T.M. Connolly, E.A. Boyle, A. Wilson, and A. Razak, "A systematic literature review of games-based learning empirical evidence in primary education," Comput. Educ., vol. 102, pp. 202-223, 2016.

[25] J. Lymbery, "The potential of a game-based learning approach to improve learner outcomes," CINZS, vol. 24, no. 1, pp. 21-39, 2012

[26] D.W. Shaffer, K.R. Squire, R. Halverson, and J.P. Gee, "Video games and the future of learning," Phi Delta Kappan, vol. 87, no. 2, pp. 105 111,2005

[27] L.S. Vygotsky, Mind and society: The development of higher mental processes. Cambridge, MA: Harvard University Press, 1978.

[28] J. Bishop and M. Verleger, "The flipped classroom: A survey of the research," in 120th ASEE Annu. Conf. \& Exposition, Atlanta, GA, 2013.

[29] Y. Fadol Y, H. Aldamen, and S. Saadullah, "A comparative analysis of flipped, online and traditional teaching: A case of female middle eastern management students," Int. J. Manage. Educ., vol. 16, no. 2, pp. 266$280,2018$.

[30] M.K. Lee, "Flipped classroom as an alternative future class model? Implications of South Korea's social experiment," Educ. Technol. Res. Dev., vol. 66, no. 3, pp. 837-857, 2018.

[31] D.A. Kolb, Experiential learning: Experience as the source of learning and development. Englewood Cliffs, N.J.: Prentice-Hall XIII, 1984

[32] D.A. Schön, The reflective practitioner: How professionals think in action. Aldershot: Avesbury, 1991

[33] D.W. Johnson, and R.T. Johnson, "Cooperative, competitive, and individualistic learning," J. Research \& Develop. Educ., 1978.

[34] R.T. Johnson, D.W. Johnson, and M.B. Stanne, "Effects of cooperative, competitive, and individualistic goal structures on computer-assisted instruction," J. Educ. Psychol., vol. 77, no. 6, p. 668, 1985.

[35] R.E. Slavin, "Cooperative learning," Rev. Educ. Res., vol. 50, no. 2, pp 315-342, 1980

[36] Z. Qin, D.W. Johnson, and R.T. Johnson, "Cooperative versus competitive efforts and problem solving," Rev. Educ. Res., vol. 65, no. 2 , pp. 129-143, 1995.

[37] J. Whitehill, and M. Seltzer, "A crowdsourcing approach to collecting tutorial videos - toward personalized learning-at-Scale," in 4th ACM Conf. Learning at Scale, Cambridge, MA, 2017.

[38] J.K. Ellington, and E.C. Dierdorff, "Individual learning in team training Self-regulation and team context effects," Small Group Research, vol. 45, no. 1, pp. 37-67, 2014.

[39] R. Vuorikari, Y. Punie, S.C. Gomez, and G. Van Den Brande. (2016) DigComp 2.0: The digital competence framework for citizens. Update phase 1: The conceptual reference model [Online]. Available: https://ec.europa.eu/jrc/en/publication/eur-scientific-and-technicalresearch-reports/digcomp-20-digital-competence-framework-citizensupdate-phase-1-conceptual-reference-model

[40] Becreo technologies. Scottie Go! [Online]. Available: https://scottiego.com/en/

[41] Lifelong Kindergarten Group at the MIT Media Lab. Scratch [Online] Available: https://scratch.mit.edu

[42] Micro:bit Educational Foundation. Micro:bit [Online]. Available: http://microbit.org

[43] Python Software Foundation. Python [Online]. Available: https://www.python.org 